\title{
Türk Tefekkür Tarihini Temellendirmede Yeni Bir Yorum Denemesi
}

\author{
Hüseyin Âdem TÜLÜCE*
}

Atıf / @-- Tülüce, H.A. (2018). Türk Tefekkür Tarihini Temellendirmede Yeni Bir Yorum Denemesi, Çukurova Üniversitesi Ilahiyat Fakültesi Dergisi, 18 (1), 513-533.

Öz- Her medeniyetin kendine özgü bir felsefe yapma biçimi vardır. Düşünmenin meseleleri aynı olsa bile ifade etme ve dile getirme şekilleri farklıdır. $\mathrm{Bu}$ yönüyle düşünmenin evrensel yönü genel çerçevede aynı konulardır. Fakat bu aynı olma durumu bütünü kapsamaz. Öte yandan düşünmenin yerel yönü bizim düşüncelerimizi belli bir sistematik ve kavramsal yapı içinde dile getirmemizi sağlar. İşte bu noktada özgün bir felsefi tefekkür evrensellikle yerellik arasında durur. Evrensellik, konu bağlamında öne çıkarken yerellik ifade bağlamında öne çıkar. Burada anlam, evrensel boyutu imlerken anlamın dile gelmesi yerel boyutu imler. Bu çerçevede biz nazar ve mükaşefe kavramlarını yerellik ve evrensellik bağlamında ele aldık. Bunun mümkün olup olmadığını Prof. Dr. Süleyman Dönmez, Prof. Dr. Teoman Duralı, Prof. Dr. Yalçın Koç'un ve Prof. Dr. Ihsan Fazlıoğlu'nun düşünceleri çerçevesinde tartıştık. Bu çerçevede "nazar ve mükaşefe" kavramları üzerinde durduk. Çalışmamızda Prof. Dr. Süleyman Dönmez'in düşünce yolunda tin, ruh, mana, iç anlamında yorumlanan "nous", kavram ve düşünce öncesi durumu ifade etmek için kullanmıştır. "Logos" kavramı ise dış, akıl, düşünce sistematiği anlamında ele alınmıştır. Gerek "nous" gerekse logos kavramı hem Süleyman Dönmez' in hem de Yalçın Koç' un eserlerinde farklı şekillerde ele alınsa da aynı anlamda kullanılan kavramlardır. Üzerinde durduğumuz "nazar ve mükaşefe" kavramlarını temel olarak Sühreverdi'nin işrak felsefesinden alsak ta İslam düşünce geleneği içerisinde felsefede, kelamda ve tasavvufta sıkça kullanılan kavramlardır. "Nazar", çalışmamız bağlamında bilgiye ulaşmada rasyonel aklı temsil ederken "mükaşefe" ise bilgiye ulaşmada sezgiyi merkeze alır. Öte yandan makalemizde Ihsan Fazlıoğlu'nun "gerçeklik küresi" terkibini, tarihi müktese-

Makalenin gelişi: 04.04.2018; Yayına kabul tarihi: 12.06.2018

* Çukurova Üniversitesi SBE Felsefe ve Din Bilimleri Anabilim Dalı (Din Felsefesi) Doktora Öğrencisi, e-posta: hatulucu@mynet.com (ORCID: 0000-0003-3999-739X) 
batı okuma konusunda değerlendirdik. "Gerçeklik küresinin" ne olduğunu ve fizik ilimlerin bu gerçeklik küresi ile olan bağını ortaya koymaya çalıştık. Teoman Duralı'nın rasyonel akla dayalı "logos" felsefesi ile Yalçın Koç' un gönle dayalı "nous" anlayışını karşılaştırdık. Süleyman Dönmez'in "keşfi inşa” yönteminin ne olduğunu ve yeni bir yöntem olarak durduğu yeri ifade etmeye gayret gösterdik. Tüm bunlarla birlikte "nous" ve "logos" kavramlarının Batı felsefe tarihi içinde hangi anlamda kullanıldığına, anlam kaymasına uğrayıp uğramadığına değindik.

Anahtar sözcükler- Nazar, mükaşefe, nous, logos, Türk felsefesi, batı felsefesi

\section{$\S \S \S$}

\section{Giriş}

Çalışmamızda, Türk tefekkür tarihini yeni bir bakış açısıyla okumanın imkânı meselesini anlamaya ve yorumlamaya gayret gösterdik. Bu çerçevede Prof. Dr. Yalçın Koç, Prof. Dr. Teoman Duralı, Prof. Dr. İhsan Fazlıoğlu ve Prof. Dr. Süleyman Dönmez'in düşünceleri bağlamında "Bir Türk felsefesi var mı, varsa Türk felsefesinin özellikleri ve kavramsal zemini nasıldır?" sorularını karşılaştırmalı bir şekilde ele aldık. Diğer yandan bir Türk felsefesi varsa bunun ifade edilebilme yani söze gelme imkânı üzerinde durduk.

Bu meseleyi ele alırken "Felsefenin ne olduğu? Bir düşüncenin felsefi olabilmesi için hangi özelliklere sahip olması gerektiği?" gibi birçok soruyu cevaplandırmak gerekir. Bu anlamda üzerinde durduğumuz sorular, "Felsefe, sadece Antik Yunan'dan geldiği şekliyle mi kabul edilip yorumlanmalı yoksa diğer medeniyetlerin ortaya koyduğu düşünsel birikimlerde felsefi olarak kabul edilmeli mi?" Mesela "İslam düşünce tarihindeki Meşşai felsefenin dışında mülahaza edilen kelamî ve tasavvufî çizgiyi nereye koyacağız?" Veya "bugün var olan Batı felsefesi tüm insanlık için takip edilmesi gereken tek felsefe yapma şekli midir?" "Batı felsefesinin gözünde Anadolu coğrafyasında var olan irfani anlayışın felsefi bir değeri var mı? Diğer yandan "Felsefe, sadece rasyonel bir zemine mi dayanmalıdır yoksa duyusal, kültürel ve irfani bir boyutu var mıdır?". Bu ve benzeri birçok soruda ortaya koymaya çalıştığımız husus tek bir felsefe yapma şekli mi yoksa birden fazla felsefe yapma şekli mi vardır?" meselesini anlamaya ve yorumlamaya çalışmaktır. 


\section{1- Felsefe Yapma Biçimleri}

Bugün Türkiye'de ve dünyanın birçok üniversitelerinde felsefe yapma şekli Batı felsefesi merkezlidir. Akademik çevrelerde, felsefenin, hem sistematik açıdan hem de kavramsal olarak Batı felsefesi merkezli olduğu görülmektedir. Ifade etmeye çalıştığımız temel nokta, Batı'nın felsefe yapma biçimini yok saymak değil, bu felsefe yapma biçiminin "mutlak ve merkezi" noktaya alınması ve diğer medeniyetlerin düşünce ürünlerinin yok sayılmasıdır.

Günümüzde, bilimde, sanatta, teknolojide bütün boyutlarıyla otoriter bir konuma sahip olan Batı medeniyeti kendisini bütün milletlerin ve medeniyetlerin merkezine alarak tek tip bir insan anlayışını ortaya çıkarmıştır. Kullanılan yöntemler ve kavramlar dünyanın her yerinde, ilmî ve akademik çevrelerde "hakikat" gibi değerlendirilmektedir. Tek doğrunun kendi felsefî, sanatsal, edebî, siyasî ve ekonomik anlayışları olduğunu iddia etmektedirler. Hâlbuki milletlerin ve medeniyetlerin kendilerine özgü bir düşünüşü, hissedişi ve eyleyişi vardır. Bu düşünüş, hissediş ve eyleyiş süreçleri milletlerin şahsiyetlerinin kendilerine mahsus olması açısından önemli bir yere sahiptir. Fakat bugün ne yazık ki gerek ülkemizde akademik çalışmalarda gerekse İslam coğrafyasındaki ilmi araştırmalarda kendine mahsus bir yöntem henüz geliştirilememiştir.

Son yıllarda bir Türk felsefesinin olup olmayacağına ilişkin Yalçın Koç, Teoman Duralı, Süleyman Dönmez ve İhsan Fazlıoğlu gibi ve daha ismini anamadığımız birçok değerli akademisyen bir takım fikirler geliştirmekte ve öneriler ileri sürmektedirler. Bir Türk felsefesini imkânı meselesini ele alırken ilk olarak Süleyman Dönmez ile başladık. Yöntem konusunda, Süleyman Dönmez "her milletin ve medeniyetin kendine özgü bir ilmi birikim ve sürecinin olduğunu, yapılması gerekenin o medeniyetin müktesebatının ilk önce keşfedilmesi ve daha sonrada inşa edilmesi gerektiğini" söyler. Dönmez, çalışmalarında kullandığı yöntemi "keşfî inşâ" olarak adlandırır.

Dönmez, Türk tefekkürünün, "öncelikli olarak geçmişten yola çıkılarak yapılabileceğini ve anlaşılabileceğini" ifade eder. "Keşfî inşâ" yöntemine göre yapılması gereken geçmişten bugüne gelmektir. İlk önce geçmişte nelerin var olduğunu keşfetmek yani tarihi zemini fikrî bir çerçevede incelemek gerekir. Daha sonra tarihi zemin üzerinden ortaya çıkan fikri merkeze alarak ciddi ve tafsilatı bir okuma yapılır. Geçmiş, ölü bir mazi değildir. Geçmişe, anlamsız olaylar bütünü olarak baktığımızda geleceğimizi anlamlı bir şekilde kurmamız mümkün değildir. Peki, geçmişle nasıl bir ilişki şeklimiz olmalıdır? Geçmişe, 
hangi yöntemle yaklaşmalıyız? Öncelikle geçmiş, övgünün ve sövgünün bir nesnesi olmaktan çıkarılıp ilmi bir araştırma ve anlamanın zemini yapmalıdır. ${ }^{1}$

Bu noktada üzerinde hassasiyetle durulması gereken mühim bir mesele ile yüz yüzeyiz. Arkamızda dokunamadığımız büyük bir tarihi, düşünsel birikim var ve şu an içinde yaşadığımız ve dokunabildiğimiz güncel bir hayat var. Yaşadığımız hayatla geçmişimiz arasındaki bağı kurmak ve bunu belli bir yöntemle yapmak oldukça zor, ama gerekli görünüyor.

Dönmez'in "keşfî inşâ" yöntemi ile geçmişte var olan tüm birikimler yani malum ortaya çıkarılıp dış gerçeklik denilen şey anlaşılmaya çalışılır. Öncelikli olarak kendi tarihimizin gerçekliği kavrayış alanına çıkarıı ve daha sonrada anlama, yorumlama aşamasına geçilir. Tarih, duygunun konusu olmaktan çıkarılıp düşüncenin konusu haline getirilir ve bunun içinde ilmî araştırmalar yapılmak zorunludur. Tarihî gerçekliğin yani kendi varlık alanımızın keşfinden ve kavranışından sonra bir inşâ süreci başlayabilir. Her inşâî süreç muhakkak bir keşfin sonucunda gerçekleşir. Bu süreç donuk değil canlı bir süreçtir. "Keşf" ve "inşa" sürekli devam eden ve gelişen süreçlerdir. Bununla birlikte unutulmaması gereken her "keşf" kesinlikle bir "inşâ" sürecini zorunlu kılar. "Keşf ve inşâ" her daim iç içedir ve sürekli birbirlerini açarlar. Bu yönüyle sadece keşfi merkeze almak bizi anlaşılamayan ve yorumlanamayan tarihsel malumatla karşı karşıya getirirken tarihsel birikimin olmadığı inşalarda temelsiz ve anlamsız olmaya mahkûmdur. ${ }^{2}$

"Keşfî inşa" yöntemi, bir felsefi düşünüşün kapılarını açabilir mi? Burada tarihi birikimlerin yorumlanışı bağlamında bir çıkış yolu bulunabilir mi? Dönmez, bu noktaları genel bir biçim de ele alır. Meselenin detaylarını, mesela inşanın nasıl gerçekleşeceğini ifade etmez. Önerisi, kavramsal ve sistematik olarak detaylı olmasa da bütünü görme anlamında yorumlanabilir.

Öte yandan Dönmez, yeni bir felsefi okuma çerçevesinde "ontoepistemik" kavramını açıklar. "Onto-epistemik" kavramı klasik felsefi düşünce içerisinde kullanılmaz. Tabi ki böyle bir anlamlandırma birtakım problemleri de beraberinde getirir. Dönmez, "vücut ve mevcut kavramları ontolojiktir" der. "Varlığın veya var olanın bilgisi ise epistemolojiktir." Yani varlıkları ele alan ontoloji iken bilgiyi ele alan epistemolojidir. "Onto-epistemik" kavramı Dönmez'in kendine özgü bir şekilde ele aldığı ve yorumladığı bir kavramdır. "Onto-

Dönmez, S, Keşfedilmeyi Bekleyen Medeniyet: Felsefenin Batı Dışı Referanslarına Eleştirel Bir Katkı, Adana, Karahan Kitapevi, 2015, s. 12.

2 Dönmez, Keşfedilmeyi Bekleyen Medeniyet, s. 13. 
epistemik", zihnin dışında bilenden bağımsız var olanın bireydeki tezahürüdür. Dış dünyada var olanın insandaki yansımasıdır. ${ }^{3}$

Bu noktada "onto-epistemik" kavramının en önemli problemi zihnin dışında bilenden bağımsız varolan ile bireydeki bağın nasıl gerçekleşeceğidir? Var olanlar, insan zihnine kavramlar vasıtasıyla ulaştığında artık dışardaki var olanlar gibi olmayacaktır. Çünkü kavramlar, var olanları gördüğümüz pencerelerdir. Bu yüzden var olanların kendilerine özgü niteliklerini tamamen görmek ve anlamak mümkün görünmemektedir. Burada eleştirilmesi gereken şu olabilir, varlıktan kopuk salt düşünme, düşünceyi üretir. Fakat böyle bir düşünme şekli varlıktan kopuk olduğu için varoluşun canlılığından ve sahihliğinden uzaktır. Varlıktan uzaklaşma meselesini Martin Heidegger Batı felsefesinin Descartes sonrası felsefi düşünce sürecinde görmüş ve bunu "Varlık ve Zaman" adlı eserinde temellendirmiştir.

Türk düşüncesinin imkânı bağlamında sadece üretilmiş düşünceye bağlı kalmak ve tek başına düşünce üzerinden Türk tefekkür tarihine yönelmek parçalanmışlığı arttırır. Çünkü var olandan uzak bir düşünme sadece düşünsel bir kurgu olmaktan ileri gitmez. Bu anlamda bir Türk felsefesinden bahsedilecekse varlıktan yola çıkılmalı ve düşünce ürünlerini varlığın kendi gerçekliği içinde değerlendirmelidir. Burada varlıktan ve var olandan kast ettiğimiz birincisi kendi düşünce geleneğimizdeki "vücudu'ul aynî" yani "dış dünyada varlık" ikincisi ise "vücudu'z zihnî" denilen "zihnî varlık"tır. "Dış dünyada varlık", en genel anlamda varlık olarak adlandırılabilir. "Zihnî varlık" ise dış dünyaya nazar ederken oluşturduğumuz kavramsal yapılardır. Üzerinde durduğumuz konu, varlık değişmez fakat varlığa olan yaklaşımımızda kullandığımız kavramsal yapılar ve yorumlar değişebilir. Bugün bir Türk düşüncesi oluşturulacaksa tarihsel süreçte oluşmuş kavramsal yapıları ve yorumları mutlaklaştırmadan kendi dilimizin imkânlarını da kullanarak yeni bir düşünme yöntemi ortaya koyulabilir. Şayet Türk düşüncesi, kendi varoluşsal gerçekliğini kaybederse bir kurgu olmaktan kurtulamaz. Mesela Batı felsefesi kendi gerçekliği üzerinden yükselmiştir. Fakat bu tarihsel ve varoluşsal gerçekliğin birikimleri varoluşçu filozoflar tarafından ciddi anlamda tenkit edilmiştir. Bugün Türkiye'de üretilen felsefe kendi tarihsel zemininden ve gerçekliğinden yoksundur. Bunun bir sonucu olarakta sahih ve gerçek olmadığı görülmektedir.

Bu çerçevede Dönmez'in "onto-epistemik” kavramsallaştırması yukarıda bahsettiğimiz meseleyi anlama noktasında bir çıkış olmasına rağmen bakış açısı ve düşünme şekli açısından modern düşüncenin tuzağına düş-

3 Dönmez, Keşfedilmeyi Bekleyen Medeniyet, s. 22. 
mektedir. Varolan ve tarihî birikim sanıldığı kadar saf ve olduğu gibi yorumlanabilen bir "malum" değildir. Geçmiş, bugünün bilgi ve düşünce sınırlarından bize görünür. Geçmişin düşünce ürünleri, kendi zamanlarının paradigmaları ve "üst dilleri" içinde bir anlama sahiptir. Bu nedenle "onto-epistemik" bir çıkış içinde ancak bir ideal barındırırsa anlamlı olur. İhsan Fazlıoğlu'nun ifade ettiği gibi "tarih, geleceğe yönelik projeleri ve idealleri olan milletler için anlamlıdır."

Dönmez, Türk tefekkür tarihinin iki şekilde incelenebileceğini belirtir. Birincisi "malum üzerinden" yapılabilecek bir inceleme iken ikincisi "fikriyat üzerinden" yapılan bir incelemedir. "Yalnızca fikirler üzerinden yapılan bir inceleme felsefidir. Malum üzerinden yapılan bir inceleme ise felsefi olana açıktır yani felsefîleştirilebilir. Türk felsefe tarihi incelemelerinde öncelikle yapılması elzem olan malumun esas alınarak malumdaki fikre ulaşmaktır. Kendi malumumuza dayanmayan felsefî incelemelerle bize ait bir düşünce dünyası kuramayız. ${ }^{\prime \prime}$

Bize ait olan bir düşünce dünyası kurabilmemiz için Türk düşünce tarihindeki bilme tarzını ve kendi varlık temellerimizi ortaya çıkarmamızla imkân dâhilinde görünmektedir. Türkiye'de yapılan felsefî çalışmalarda iki yanlış bulunmaktadır. Bunlardan ilki, kendimize ait olanı sadece Batı düşünce sistematiği üzerinden okumak ve değerlendirmeye çalışmaktır. Bu, tam da şu anlama gelir, kendi tarihsel birikimimizi Batı felsefesinin kavramsal yapısı içinde çözümlemeye çalışmaktır. Bu, kendimizi, kendimiz olarak değil başkası olarak anlamayıp görmektir. İkincisi ise başkalarının malumlarını kendi malumumuz gibi ele alıp yorumlamaktır. Batı'nın tarihsel birikimini kendi birikimimiz gibi inceleyip, araştırmaktır. Buradaki problem kendimizi tanımak için sürekli başkasının anlaşılmaya çalışılmasıdır. Bu iki inceleme şeklide sonunda ancak yabancılaşma üretirler. Yöntem olarak yapılması gereken ise varlık alanımızı kendi kavramlarımızla anlamaya ve yorumlamaya çalışmaktır. Bu başka milletlerin yok sayılması anlamına gelmemektedir. İnsanlığın düşünce birikimine uzak durmak bizi körleştirir. Fakat yanlış olan önümüze çıkan her milletin varlık, bilgi ve ahlak anlayışını sorgulamadan, tartışmadan olduğu gibi almaktır.

Türk düşüncesinin serencamı bağlamında çıkmazımız, aydınlarımız ve ilim adamlarımızın yaklaşık olarak 200 yıldır kendi sofrasını kurup kendi yemeğiyle beslenmekten ziyade Batı medeniyetinin kurduğu düşünce sofrasından beslenmeleridir. Bu sebeple de yerli, özgün, dertlerimize derman olan ve sahih bir düşünce geleneği ortaya çıkmamaktadır. Bu sebeple Batıdan

Fazlıŏlu, Kendini Aramak, İstanbul, Papersense Yayınları, 2014, s. 73.

Fazlıŏlu, Kayıp Halka, s. 42. 
aldıklarımızı da kendi sözümüz haline getiremiyoruz. Konuyu daha da somutlaştırırsak, Türk düşünce tarihine baktığımızda tarih, coğrafya, tıp, tasavvuf, kelam, matematik ve felsefe ürünleriyle birlikte masallarımız, hikâyelerimiz, şiirlerimiz ve destanlarımız vardır. Bu çerçevede ilk önce bu birikimin okunması, farklı yorumlara tabi tutulması ve kavramsal yapılarının oluşturulması, sahih bir düşünce geleneğinin oluşturulması açısından önem arz eder.

Öte yandan, her medeniyetin kendine has gelenek, görenek, hayat anlayışı ve düşünce sistematiği vardır. Bu medeniyetin düşünce ürünlerinin anlaşılabilmesi için bu medeniyetin kendisine ait olan düşünce yönteminden yola çıkmak gerekir. Burada iki yönlü bir problem mevcuttur. İlki başka bir milletin düşünce ürünlerini tanımadan kendi düşünce anlayışımızla o millete yaklaşırsak düşünce aynasında gördüğümüz sadece kendimiz oluruz. Bu nedenle düşünce ürünlerini ve onların ortaya çıktığı tarihi ve coğrafi durumları bilmeden onları anlamamız mümkün değildir. Bugün şarkiyatçıların yaptığı İslam felsefesi çalışmalarında bu durum çok aşikâr bir şekilde müşahede edilmektedir. Kendi kavramsal dünyalarıyla ve tarihsel algılarıyla İslam medeniyetinin tarihsel dönemlerini ve şahsiyetlerini incelerken doğal olarak kendi dünya tasavvurlarının yönelimleriyle değerlendirmeler yapmaktadırlar.

\section{2- Logos ve Nous}

Batı felsefesi tarihinde "logos"; "konuşma, açıklama, hesap ve akıl" manasında kullanılmaktadır. ${ }^{6}$ Ayrıca "iç düşüncenin ifade edildiği söz, iç düşüncenin veya aklın kendisi" olarak da tanımlanır. Logos' u "zihinde var olanın dil ile ifadesi" şeklinde tanımlayabiliriz. Bu yönüyle "logos" felsefe yapmanın çıkış noktası olarak açıklanabilir. Logos merkezli okuma biçimi Batının, Aristoteles ile ortaya koyduğu, sistemleştirdiği felsefe yapma biçimidir. Bu felsefe yapma biçimi hakikate ulaşmada bir imkân olarak değerlendirilebilir ve önemli bir yere sahiptir. "Nous", Batı felsefe tarihinde doğru bir şekilde açıklanabilmiş ve anlaşılabilmiş bir kavram değildir. Genel itibariyle "logos ve nous" birbirine karıştırımaktadır. Peki, "nous" nedir? Nous' un, kelime anlamı "tin, zekâ, akıldır." Nous, "tinsel veya manevi kudret; mana, gönül, yürek, derûn; derûni anlayış ve kavrayış" anlamında kullanılmaktadır. "Nous”, Antik Yunan'dan beri birliğin ilkesi olarak görülmüştür. ${ }^{7}$

Peters, F. E, Antik Yunan Felsefesi Terimleri Sözlüğü, İstanbul, Paradigma Yayınları, Çev. Hakkı Hünler,2004, s. 208

7 Peters, Antik Yunan Felsefesi Terimleri Sözlüğü, s. 210. 
"Logos"un yorumlanmasındaki zorluğun nedeni yaygın olarak kullanılan bu kelimenin terim anlamında ilk defa ne zaman kullanıldığıdır. Logos'u ilk olarak "oran" anlamında kullanan Herakleitos'tur. Platon, logos sözcüğünü çok farklı biçimlerde kullanır. Platon'da logos, doğru ve analitik bir açıklamadır. Bu yönüyle de epistemolojik teoriye rehberlik eder. Bununla birlikte bir şeyin hesabını verme anlamı da vardır. Öte yanda insanın bildiği bir şeyin hesabını (1ogos) verebilmesi, doğru bilginin(episteme) temelidir. ${ }^{8}$ Stoacılara göre logos evrendeki meydana getirici güçtür. Bununla birlikte iç logos(düşünme) ve dış logos(konuşma) şeklinde de kullanılmıştır. ${ }^{9}$

Öte yandan nous'a baktığımızda, Platon, insan ruhunda ki içkin nous ile birlikte kozmik nous'tan bahseder. Ve nous'un yapıcı bir özelliği vardır. Nous'un ruhta var olmasının nedeni idealara olan bağımlılığıdır. Nous, ruhun ideaları algılayıp kavrama kabiliyetidir ${ }^{10}$ Aristoteles, insani ve tanrısal "noesis"i karşılaştırır. İnsan bedenden ve noetik bir ruhtan oluşan bileşik bir varlıktır. "Noesis" kuvveden fiile bir geçişi gerektirir. Aristoteles'te, kendisinin nous olarak isimlendirdiği sezgiye dayalı bir bilgi şekli vardır, fakat bu bilgi biçimi epistemolojik zemindedir. "Mistik" bir bağlamda görünmez. ${ }^{11}$

Günümüz felsefesinde, "nous” yaklaşımda iki yol vardır. Bunlardan ilki, Ortodoks anlayış diyebileceğimiz anlayıştır. Bunlara göre nous'un işlevi, ilk ilkeleri "ilk ilkeler" olarak sezgisel bir şekilde kavramayabilmektir. Epistemeye sahip olduğumuzdan emin olabilmek için, epistemeye esas olan ilk ilkeleri kabul etmemiz gerekir. Ancak böyle bir bilgiyi sadece sezgisel bir yeti olan nous verebilir. ${ }^{12}$ İkinci görüş ise emprist görüştür. Bu görüşte olanlar "nous"un ilk ilke ve sezgi olarak kabul edilemeyeceğini ve onun tümevarım yoluyla ortaya çıktığını iddia ederler. ${ }^{13}$

Dönmez'e göre Antik Yunanda "nous ve logos" bir bütünün iki farklı boyutudur. "Logos ve nous" kelimeleri Türkiye'de genelde aralarındaki ince ayrıma dikkat edilmeden kullanılır. Ancak "nous ve logos", iç-dış ya da içlemkaplam bakımından eşdeğer değildir. Antik Yunanda felsefesinin önemi mitostan logosa geçebilme başarısındadır. Logos merkezli düşünüşün getirisi, elbette küçümsenemez. Fakat varlığa logostan bakmakla "nous”tan bakmak,

\footnotetext{
Peters, Antik Yunan Felsefesi Terimleri Sözlüğü, s. 210.

Peters, Antik Yunan Felsefesi Terimleri Sözlügü, s. 210.

Peters, Antik Yunan Felsefesi Terimleri Sözlüğü, s. 247-48.

Peters, Antik Yunan Felsefesi Terimleri Sözlügü, s. 249-50.

Sarı, M.A, Aristoteles'te İlk İlkelerin Bilgisi Ve Nous Üzerine, Kaygı dergisi, 2011/16, s. 127.

Sarı, Aristoteles'te İlk İlkelerin Bilgisi ve Nous Üzerine, s. 125.
} 
ifade edildiği gibi, sonuçları itibariyle eşdeğer değildir. Eski Yunan "nous"'u hisseder, ama felsefesine geçemez. Eski Yunanın mirasçısı olan Batı felsefesi de aynı yolu takip eder. ${ }^{14}$

Dönmez, "Logos"un maddeden mânâya/tenden tine geçme çabası olan zahiri akıl olduğunu ifade eder. "Logos", zahirde olanı dile dökmenin ölçütüdür. Zamanla logos'a mantık denilmiştir. Mantık, hesabî çalışır ve rasyoneldir. Bu nedenle logos kelimesi Latinceye "sermo, oratio, ratio", Arapçaya ise "nutuk" olarak çevrilmiştir. ${ }^{15}$ Öte yandan " nous", rasyonel aklı kuşatan içtir. Aristoteles, onun tikelden tümele götüren bir sezgi olduğunu düşünür. Verilen hükmün doğru olduğunu kesinleştiren öznel bir duyuştur. İlk ilkelerin kesin bilgisine doğrudan eriştiren bir düşünce erdemidir ve deneyimle güç kazanır. ${ }^{16}$ Eski Yunanda logos esasında nous felsefesi yapmayı deneyen ilk sistematik filozof Aristoteles'tir. Aristoteles'in hocası olan Platon ise, noustan çok söz etmez. Esasen Platon, "nous felsefesine" daha yakındır. Belki de, bu yüzden ona Attikeli Musa denilmiştir. Ama o da, muhtemelen, eski Mısır üzerinden aldığı nous fikrini Atina'da kaybeder. Neticede nous içsel bir duyuş olarak logosun altına sıkışır kalır. Nous niçin logosun gölgesinde kalmış olabilir? Bu sualin cevabı, kuşkusuz eski Yunanın din anlayışıyla yakından ilişkili görünmektedir. Nihayetinde içe tekabül eden nous, dinsel olanla içlidışlıydı. Ancak eski Yunan'ın din dediği ise, mitostu. Doğal olarak mitostan logosa doğru yapılan harekette mitosun içinde yaşatılan nous, logos ile çekip çıkarılmak istendi. Ancak iç olanın dış ile kurulması mümkün olmadığından başarılı olunamadı. ${ }^{17}$

Yukarıda bahsettiğimiz bağlamda "logos ile nous" arasında nasıl bir ilişki vardır? Rasyonel yetiye dayalı ve mantıksal olan "logos", "rasyonel ve kavramsal temelde sözün kurulması" manasında anlaşılabilir. Mantıksal yönden oluşturulmuş rasyonel bir zemin olarak "logos", insanı, âlemi anlama yeterliliğine ne kadar sahiptir? "Logos", tek başına hakikati açma ve kavrama yeterliliğine sahip midir? Kavramlarla hakikate ulaşma imkânımız var mıdır? Yani "söz"ün bize hakikati verebilme gücü var mıdır?

"Nous", kendi başına bir felsefe yapma imkânı verebilir mi? Burada "nous", "öz" olarak ifade edilebilirken "logos" ise bu "öz"ün "ifadeye dönüştü-

14 Dönmez, S, Emanet Ahlakı Türk Ahlak Felsefesine Giriş, Adana, Karahan Kitapevi, 2015, s. 23.

15 Dönmez, Emanet Ahlakı Türk Ahlak Felsefesine Giriş, s. 27.

16 Dönmez, Emanet Ahlakı Türk Ahlak Felsefesine Giriş, s. 28.

17 Dönmez, Emanet Ahlakı Türk Ahlak Felsefesine Giriş, s. 34.

ÇÜiFD, 2018, cilt: 18, sayı: 1, ss. 513-533 
rülmesi" olarak değerlendirilebilir. Nous (mükaşefe) ve logos(nazar) bir, insanoğlu için bir bütünün iki yarısı gibidir. Logos'un merkezinde "dil ve söz" varken nous' un merkezinde "mana ve öz" vardır. "Nous" sayesinde insan bir dönüşüm yaşayabilir. Söz ile ifade edilmesi zor olan özü kavrar. Fakat öz' ün ifadeye gelmesi insan için çok önemli olduğu için "logos" olmadan "nous" noksandır. "Logos" üzerinden felsefe yapma, kavramlarla hakikati aramaya çaIışmaktır. "Nous" ile hakikate ulaşılabilir ama dile gelmediği için felsefe yapma yani düşünüp kavramsallaştırma imkânı yoktur. Yani doğrudan nous' la hakikat yolculuğu neredeyse mümkün değildir. Filozoflar, logos' u kullanarak nous' un ışığını görebilirler. Öz, ancak söze gelirse bir düşünme gerçekleşebilir.

Bilgi ve düşünce noktasında Fazlıoğlu'nun yöntemi ise Francis Bacon' dan ilham alarak açıkladığı üç hayvan benzetmesidir. Bu hayvanlar, sırasıyla karınca, örümcek ve arıdır. Karıncanın özelliği sürekli toplaması ve biriktirmesidir. Örümceğin özelliği ağ örüp bir sineğin takılmasını beklemektir. Arı, çiçeklerden özü toplar, yutar, yoğurur ve bal ortaya çıkarır. Bu benzetme bağlamında bilginin toplanması tek başına yeterli değildir, bununla birlikte bir paradigma kurup bu paradigma çerçevesinde anlamlar yakalamakta yeterli görünmemektedir. Yapılması gereken çok sağlam bir malzeme ve çok sağlam bir teoriyle özgün düşünce ve bilgilere ulaşmaktır. ${ }^{18}$

Bununla birlikte Fazlıoğlu, Türkiye' de yapılan felsefe-bilim çalışmalarının gerçeklik kürelerinin olmadığını ifade eder. Bunun bir sonucu olarak da Türk felsefesi ikinci dereceden bir düşünce haline gelir. Birinci dereceden düşüncenin olabilmesi için bilimsel çalışmaların yani mahsus' un bilinmesi gerekir. Ardından bu mahsus' un "ma'kul” e dönüştürülmesi ve son olarakta bu "ma'kul' ün tahkik' i” yani felsefesi ortaya çıkar. "Ma'kul" dikkate alınmadan yapılan tüm çalışmalar söz bağlamında anlam ifade etseler de mefhum olarak anlam ifade etmezler. ${ }^{19}$

"Gerçeklik küresi”, bir medeniyetin kendi tarihi, coğrafi, bilimsel, siyasi, ekonomik bütünüdür. Bu gerçeklik zemini olmadan yapılan tüm felsefi çaIışmalar birer edebiyat olmaktan öte gitmez. Burada "mahsus'un" bilinmesi bu "gerçeklik küresinin" bilinmesidir. Bilinen bu gerçekliğin ifadesi ise "ma'kulleştirmedir". İşte bu noktada felsefenin ortaya çıkabilmesi için "tahkiki aşamaya" geçmek gerekir.

Fazlıoğlu, insan idrakinin tarihi bir zeminde gerçekleştiğini, mekân ve zamanla mukayyet olduğunu, mutlak olmadığını ifade eder. Tarihte ortaya

18 Fazlıŏlu, Sözün Eşiğinde, İstanbul, Papersense Yayınları, 2016, s. 58.

19 Fazlıoğlu, İ, Derin Yapı, İstanbul, Papersense Yayınları, 2016, s. 219. 
çıkmış her teorinin(nazariye) kendi "gerçeklik küresi" bilinmeden ne dediğinin anlaşılamayacağını ifade eder. ${ }^{20}$

Fazlıoğlu'nun düşünme sistematiğinde ortaya attığı "gerçeklik küresi" iki yönden ele alınabilir. Birincisi, tarih içinde düşünce eserlerinin kendi dönemlerindeki "gerçeklik kürelerini" ortaya çıkarmak ve bunun üzerine bir felsefi düşünce geliştirmektir. Ancak böyle bir durumda düşünce ürünleri daha iyi anlaşılabilir. "Gerçeklik kürelerini" dikkate almadan sadece metinler üzerinden yapılan bir felsefî okuma bizi doğru anlama ulaştırmaz. İkincisi ise bugünün dünyasının "gerçeklik küresinin" tespit ve teşrihidir ki Fazlığlu, kanaatimce bu kısımdan az söz etmektedir. Daha çok bugünü olmayan bir geçmişten bahsediyor izlenimi vermektedir. Oysa bugünün bilimsel verileri bağlamında bir düşünce sistematiği kurmak için geçmiş'in yükünü hafifletmek gerekir. Geçmiş'in ağırlığı arttıkça bugün kaybolmakta, bugünün ağırlığı arttıkça geçmiş kaybolmaktadır. Geçmiş'in kaybolması kimliksiz bir medeniyeti doğururken, bugünün kaybolması şimdinin canlılığının yok olmasını yani yaşamayan tarihi bir medeniyeti doğurur.

Bir Türk felsefesini yeniden temellendirme meselesinde kafa yoran bir başka düşürümüz Yalçın Koç’tur. Koç, Anadolu mayası adlı eserinde öncelikle "maya" ve "kültür" kavramlarını açıklar, bu iki kavramı birbirinden ayırır. Maya' yı asıl, öz ve olarak tanımlarken kültürü, bir şeyin yetiştirilmesi amacıyla ortamın hazırlanması olarak tanımlar. Tarım için toprağın hazırlanması kültüre örnektir. Koç, kültürün dışşal olduğunu bu yüzden de birlik olmadığını söyler. Maya' nın esasında ise birlik vardır. Maya, mayalanma sürecinde kendine dönüştüren bir özelliğe sahiptir. Yoğurdun mayalanmasında olduğu gibi. Maya' da tek olma varken kültürde çokluk vardır. ${ }^{21}$

Koç'un "maya ve kültür" ayrımı birlik ve birliktelik kavramları bağlamında ele alındığında daha anlamlı olur. Birlik, mana boyutunda yani içsel dönüşümü ifade ederken birliktelik ise maddi boyutu yani dışsal beraberliği ifade eder. Kültür, zahiri bir değişimdir. Maya ise içsel bir değişim ve dönüşümdür. Bu çerçevede Anadolu için kültürden değil mayadan bahsedilebilir. Anadolu mayalanmış birliğin olduğu bir coğrafyadır. Üzerinde durulması gereken nokta bu maya söze gelir mi, dil ile ifade edilebilir mi? Hemen söylersek, ifade edilemeyeceğini söyler.

Koç'a göre “Grek-Latin-kilise diyarı” kültür' ün hâkim olduğu bir coğrafyadır. Bu yönüyle felsefe yapma biçimleri birliğe dayanmaz, parçacıdır. Bu

20 Fazlıoğlu, İ, Kendini Bulmak, İstanbul, Papersense Yayınları, 2016, s. 160-161.

21 Koç, Y, Anadolu Mayası, Ankara, Cedit Neşriyat, 2014, s. 14-15. 
diyarın felsefe yapma biçimi yalnızca "logos"a dayalıdır. Öte yandan Koç, Anadolu insanının varlık dayanağının kendisi olduğunu, Grek-Latin-kilise diyarında ise birey' in yığınsal olduğunu söyler. Yığınsal bireyin temelinde Aristoteles felsefesi vardır. Bu felsefe'de insan rasyonel yetisiyle tanımlanmıştır. Bu felsefe anlayışında insan, "düşünen ve algılayan bir varlık" olarak açıklanır. Yani insanın kendiliği değil düşünmesi ve algılaması öne çıkar. ${ }^{22}$

Koç'un tasvir ettiği anlayış bir felsefi düşünüşü imkânsız kılmaktadır. $\mathrm{Bu}$ yönüyle üzerinde konuşulamayan ve yazılamayan bir alanın oluşmasına neden olmaktadır. Koç'un anlayışındaki en mühim problem mayayı mutlak olarak görmesidir. Maya, insan varlığı ile temas ettiğinde mutlak olmaktan çıkıp mukayyet hale gelir. İnsan, mutlak olanı olduğu gibi taşıyamaz, mutlak olanın mukayyet içinde ifade edilmesi elzemdir. Burada ise maya, ilahi bir boyut kazandığı için üzerinde düşünülme intimali kalmamaktadır.

Koç, Batı felsefe tarihini de maya bağlamında eleştirir. Bu medeniyette insan, "rasyonel bir varlık" olarak tanımlandığı için asli varlığından uzaklaşmaktadır. Batı düşüncesinde insan nedir? sorusunun cevabı, Aristoteles ve sonrasında ister Descartes, isterse Kant olsun, insanın düşünen bir varlık olmasıdır. İnsan, bütün olarak kendi "varlık ve mahiyeti" üzerinden değil kendinde var olan düşünme yetisi üzerinden tanımlanmıştır. "İnsan olmaklık", düşünmeyle eşdeğer görülmüştür. Bu insanın sadece kavramlarla tanınmaya çalışııması anlamına gelir.

$\mathrm{Bu}$ noktada, insanın hakikatinin sözle temellendirilerek açılmaya ve anlaşılmaya çalışılması tek boyutlu olarak olanaklı değildir. Söz ile insanın hakikatine varılmaz ama söz hakikat yolcuğunun vazgeçilmez azığıdır. Sözcüklerle sadece hakikatin tarifi yapılabilir. Bu yönüyle insanın sözle tanınmaya çalışılması, insanın özgürlüğünü ortadan kaldırır. İnsanın hakikati ve özgürlüğü, onun bütünsel mahiyetinde mahfuzdur.

Koç, Anadolu mayasındaki ferdi özgürlüğün esasının "gönül” olduğunu ifade eder. Batı da ise gönülden söz edilemez. Anadolu da insan, rasyonel bir özelliğe sahiptir. Fakat rasyonel yeti, insanın esası değildir. Anadolu insanının esası, iç olan, gönüldür. Batı insanı, içsizdir. Kilise, Batı insanına iç olmaya çalışır. Bu yüzden insan, yığınsal ve dışsaldır. ${ }^{23}$

Anadolu mayasında bilgi, mayalanma sonrasında gönlün bilinmesi ile meydana gelen bir dönüşümdür. Gönül rasyonel yeti ile kavranamaz. Dönü-

Koç, Anadolu Mayası, s. 19-21.

Koç, Anadolu Mayası, s. 30-31. 
şüm, bilince bağlı olmadığı için bireysel irade ile olmaz. Bu dönüşüm sütün yoğurda dönüşmesi gibidir. ${ }^{24} \mathrm{Bu}$ gönle mahsus olduğu için fikriyata dayanmaz. Gönle mahsus olan Anadolu mayasından Grek-Latin-kilise diyarına uygun bir felsefesi çıkmaz. ${ }^{25}$ Koç'a göre gönlün dile gelmemesi bir felsefe yapma biçimi çerçevesinde değerlendirilemeyeceği anlamına gelir.

Öte yandan Koç, "söz ile kelam" ayrımını yapar. "Kelam”, Musa peygamberin kelam ilmidir. ${ }^{26}$ Anadolu mayasında ilmin mahalli gönüldür. İlim, düşüncenin malzemesi değildir. Düşünce, ilmi kavrayamaz ve dile getiremez. Söz ise bir dile mahsus cümledir. Cümle, dildeki nesnedir. "Illimdeki kelam", dildeki nesne değildir. Bu nedenle ilimdeki kelam dil ile tesis edilemez. ${ }^{27}$ "ilimdeki kelam" yani gönül logos ile kurulamaz. Gönül, logosa yani kavramlara sığmaz. ${ }^{28}$

“ilimdeki kelamı" bilen bundan söz edebilir, cümleler kurabilir. Fakat bu, "ilimdeki kelamı" anlatamaz. Yoğurt yapmayı bilenin, bilmeyene tarif etmesi dinleyenin kendine özgü bir söz tesis etmesidir. ${ }^{29}$

Koç'un kelam' ın mutlak oluşundan bahsetmesi insanın bir yönüyle tarihsel oluşu meselesini gözden ırak tutar gibidir. İnsan, "mutlak olan kelam" ile "mutlak" olarak yüzleşecek bir özellikte değildir. İnsan, "kelamı", kendi tarihsel gerçekliği içinde düşünür, yorumlar ve dile döker.

"Mutlak olan kelamın" dile geldiği alan logostur. "Logos", zihinseldir ve kavramları merkeze alır. "Logos”, bütünün peşindedir. Değişen çoklukların ardındaki değişmeyen birliği arar. Fakat bütün, parçaların toplamından daha fazla anlama sahiptir. Çokluğun ardındaki birlik ancak mana âlemine geçerek anlaşılabilir. Birlik, logosla değil, "nou”s ile idrak edilebilir. "Logos", maddeden manaya geçme çabasıdır. Söz ile dile dökmek yeterli olmasa da gerekli ve önemlidir. Dönmez, bu noktada söz' ün öneminden bahsederek bir Türk felsefesinin "nous"u merkeze alıp "logos"la kurulabileceğini iddia eder. Koç ise sözün özü ifade edemeyeceğini söyler. Sözün, özü tam olarak vermesi mümkün değildir. Günümüzde epistemolojinin bilginin neliği meselesini ele alırken sınırlı ve belirlenmiş bir sözden yola çıktığı unutulmamalıdır. Yani, var olanları, zihinsel anlamda ele alma aslında onları kendi oluşturduğumuz kavramlarla

\footnotetext{
Koç, Anadolu Mayası, s. 50.

Koç, Anadolu Mayası, s. 54.

Koç, Anadolu Mayası, s. 178.

Koç, Anadolu Mayası, s. 181.

Koç, Anadolu Mayası, s. 195.

Koç, Anadolu Mayası, s. 198.
}

ÇÜiFD, 2018, cilt: 18, sayı: 1, ss. 513-533 
görmektir. Bu tam da Fazlıoğlu'nun ikinci elden düşünmek dediği şeydir. Muhakkak ki kavramlar gereklidir ama sorun bu kavramları merkeze almaktır. Esasında olması gereken varlık ve bilgi arasındaki canlı ve sahih ilişkinin her daim gelişerek devam etmesidir.

Bir başka ifade ile şayet kendi "gerçeklik küremize" dayanmadan logos merkezli düşünüyorsak var olanları belli bir zaman ve mekândaki yorumlanışlardan görüyoruz demektir. Logos merkezli düşünme bir yönüyle varlığa, düşünülmüş olandan bakmak demektir. Varlıkla yüz yüze gelmeden kavramlarla düşünmeye çalışmaktır. Bu sebeple logos' un altında Fazlıoğlu' nun ifadesiyle "mahsus"un olması gerekir. Buradaki logos Anadolu bilgeliğinde lafa karşılık gelirken nous ise hal ilmine tekabül eder. Anadolu, nous merkezli düşünmeyi başarabilmiştir. Yunus emreler, Ahmet yeseviler, Hacı Bektaşi veliler, Mevlanalar bu düşüncenin temelinde bulunan kişilerdir.

Dönmez, nous'un logos'a dönüşmesinde "metaforik dil" ve felsefe üzerinde durur. Mecaz'ın nous'un ifadesi açısından öneminden bahseder. Mecaz, esasen dışarıda olan hakikati herhangi bir indirgemeye tabi tutmadan kavramanın vasıtasıdır. Mecaz, düz anlatımının hakikati ifade etmede gücünün yetmediği noktada devreye girer. Mecaz, nous'u hakikate en yakın bir şekilde ifade etmenin bir yoludur. Söz'ün tükendiği aşamada belirginleşir. ${ }^{30}$ Ontolojiden kopuk düşünme, düşünceyi üretir ve epistemiktir. Dönmez'e göre "malum üzerinden değil yalnızca düşünme üzerinden Türk tefekkür tarihine yönelmek" fayda vermez. ${ }^{31}$

Bir Türk felsefesi için ilk önce düşünce tarihinin ürünleri ortaya çıkarıIır. Daha sonra ise bugünün fizik, kimya, astronomi, psikoloji, biyoloji, vb. ilimleri veri olarak alınıp tarihsel birikimimizi canlı tutmak için anlama ve yorumlamaya tabi tutulur. Elimizde var olan tarihsel birikimlerimiz yalnızca Batı felsefesinin ortaya koyduğu logos yöntemiyle anlaşılmaya çalışıldığında hakkı verilememekte ve anlaşılamamaktadır. Bununla kendi içine kapalı bir felsefe oluşturulduğu sanılmamalı. Şüphesiz ki diğer medeniyetlerin felsefeleriyle ilişkiler olacaktır. Burada esas önemli mesele, kendi düşünme yöntemlerimizi kullanarak gerçekleştirmemizdir.

Konumuz bağlamında üzerinde duracağımız bir diğer felsefecimiz Teoman Duralıdır. Duralı, öncelikli olarak felsefileşmiş olan medeniyetin en yüksek seviyede olduğunu ifade eder. Bu medeniyetin temel özelliği eleştirel düşünme seviyesine yükselmiş olmasıdır. Tarih ve coğrafya, felsefileşmiş

30 Dönmez, Keşfedilmeyi Bekleyen Medeniyet, s. 133-149.

31 Dönmez, Keşfedilmeyi Bekleyen Medeniyet, s. 22 
medeniyetin sınırlarını ve ufkunu belirler. Bir medeniyetin felsefi bir noktaya varmasında tarih ve coğrafyanın mühim bir yeri mevcuttur. Bunun sebebi tarihin zaman algısını belirlemesi iken coğrafyanın mekân algısını belirlemesidir. ${ }^{32}$

Duralı, felsefi bir seviyeye gelmede yaşadığımız coğrafyanın ve bu coğrafyanın tarih algısının önemine vurgu yaparak kavramsal bir zemin oluşturur. Diğer yandan "felsefileşmiş medeniyet" belli bir düşünce sistemi etrafında şekillenir. Böyle bir medeniyet, anlamları belirgin olan seçik kavramlara sahiptir.

Duralı'nın "felsefileşmiş medeniyet" terkibinin temel üç unsuru vardır. Bunlardan ilki tarih ve coğrafyadır. İkincisi belli bir düşünme sistematiğinin olmasıdır. Üçüncüsü ise kavramsal düşünebilmektir. Duralı'nın felsefe yapma şekli Antik Yunan felsefesinin ve bilhassa Aristoteles'in felsefe anlayışı ile paraleldir. Bu yönüyle Duralı' ya göre felsefe Aristoteles ile başlamıştır. ${ }^{33}$

Burada Duralı'nın felsefe yapma şekli nerede durur? Koç'ta Anadolu mayasının dile gelme imkânı olmadığı için nous yani mükaşefe noktasında kalmış bir tefekküre sahiptir. Duralı, ise dile gelmenin logos üzerinden gerçekleşeceğini ifade eden bir düşünme yapısına sahiptir. Bu anlamda nazar'ı merkeze alır. Dönmez ise bu düşünmeden farklı olarak nous' tan yola çıkarak bir logos'un oluşturulabileceğini söyler. Diğer yandan yukarıda bahsettiğimiz şekliyle "onto-epistemik" kavramsallaştırmasıyla bir felsefe yapma imkânının olabileceğini ifade eder.

Duralı'ya göre Osmanlının çöküşünün nedeni felsefi düşünme özelliğini kaybetmesidir. Duralı, Türkiye'de felsefe geleneğinin olmadığını ve okullarda çok basit bir felsefe öğretimi olduğunu ifade eder. Felsefi bir geleneğimiz olmadığı için üniversite hocalarının felsefe öğretimi aldıkları o kültür'ün felsefe anlayışını öğrencilerine aktardığını söyleyen Duralı, her üniversitenin felsefe bölümünün farklı ekollere sahip olduğunu ifade eder. Örneğin Boğaziçi üniversitesi felsefe bölümünde İngiliz-Amerikan, İstanbul üniversitesi felsefe bölümünde Alman geleneği, Galatasaray üniversitesi felsefe bölümünde Fransız felsefesi öğrencilere öğretilmektedir. Bu da bize göstermektedir ki hemen hemen her konuda olduğu gibi felsefe yapma konusunda da ciddi anlamda bir yabancılaşma ve köksüzlük yaşanmaktadır. Duralı, kendi tarihsel malumumuz yani keşf meselesinde Dönmez ile aynı kanaate sahipken bu malumun logos merkezli okunması bağlamında birbirlerinden ayrılırlar.

32 Duralı, Ş. T, Felsefe-Bilimin Doğuşu, İstanbul, Dergâh Yayınları, 2016, s. 27.

33 Duralı, Ş. T, Çağdaş Küresel Medeniyet, İstanbul, Dergâh Yayınları, 2016, s. 23. 
Duralı'nın üzerinde hassasiyetle durduğu bir diğer nokta dil'in felsefe için önemidir. Dil'in felsefi tefekkürün temeli olduğunu söyler. O'na göre dil bozulduğunda ve kullanılan kavramlar darmadağın olduğunda düşünmenin de düzeni olmaz. Düşünce, kavramlarla oluşan bir yapıdır. Tarifler ve önermeler kavramlar kullanılarak yapılır. Bir toplumda kavramlar ehemmiyetini kaybederlerse kendi felsefi geleneklerini oluşturamazlar. Mesela bir felsefeci cevher kavramını kullanırken bir başkası töz kavramını başka biriside substanz kavramını kullanıyor. Fakat niçin farklı kelimelerin kullanıldığı ve aralarında ne gibi farklar olduğu açıklanmıyor ise burada belli bir felsefi gelenekten bahsedilemez. ${ }^{34}$ Düşünce geleneğinin olmamasının en temel nedeni felsefi bir dil' in oluşturulamamasıdır. Bir medeniyetin gücü, dilinin gücüyle orantılıdır.

Bir millet için en mühim başarı, yüksek düşünce ürünlerine sahip olmasıdır. Duralı, Türk düşüncesinin kesintiye uğramasında yazı sisteminin üç defa değişmiş olmasını önemini vurgular. Milletler, kendi tarihi birikimleri ile bağlantılarını dil sayesinde kurar ve geliştirir. Yazı sistemi değişmiş bir milletin geçmişiyle olan bağı ortadan kalktığı için düşünce ürünleri vermesi zorlaşmaktadır. ${ }^{35}$

Duralı'nın yukarıda belirttiği etkenler muhakkak ki düşünmenin kesintiye uğramasında etkili olmuştur. Fakat asıl sorun, kendi malumumuzun yani tarihi müktesebatımızı keşfedilmemiş olmasıdır. Bir diğer sorun ise felsefe veya düşünme denildiğinde akla ilk gelen Aristoteles geleneği içindeki felsefe yapma biçimidir. Geleneğimiz içindeki kelam, tasavvuf ve düşünce ürünleri bir felsefe yapma biçimi olarak görülmemektedir. Bu sebeple bir tükenmişlik ve geri kalmışlık vurgusu sürekli yapılmaktadır. Sorunun temelinde yatan kendimizle kendimiz olarak yüzleşmeye cesaretimizin ve birikimimizin olmamasıdır. Kendi düşünce ürünlerimizle kendi inanç, kültür ve medeniyet nazariyemizden değil Batının kültür ve medeniyet nazariyesiyle baktığımız için yanlış şeyler görmekte ve hatalı, noksan yorumlar yapmaktayız.

Duralı' ya göre Türk dünyası 1600'lü yıllar ile 1800'lü yıllar arasında durgun bir dönem yaşamıştır. Bu durgunluk iktisattan siyasete her alanda kendini göstermiştir. Fakat Duralı, iki yüz yıllık bu uyuma döneminin zarardan ziyade fayda getirdiğini, Türklüğün kendine gelme imkânı bulduğunu ve ben kimim sorusunu sorabildiğini söyler. Ben kimim sorusunu sorabilmek felsefi bir bilincin ortaya çıktığını gösterir. Tanzimat'la birlikte Türk tefekkürü yeni bir

34 Duralı, Ş. T, "Felsefe ve Bilim Illişkisi", https://www.teomandurali.com/page/10/Filosof Bilimadamı ve Felsefe-Bilime İlişkin Mülakat, Erişim: 26.03.2018.

35 Duralı, Omurgasızlaştırılmış Türklük, s. 68. 
sürece girer. Bu süreçte hala kendi bilincini kaybetmeyen bir toplumla karşılaşılır. 20. Yüzyılda ise Osmanlı düşünürü farklı sebeplerle seyahat etmeye başlamıştır. Bu seyahatlerin sonucunda klasik Osmanlı âliminden farklı olarak içe dönük manevi seyahat yerine, dışa dönük olan bilgilenme süreci başlamıştır. Duralı, 1900'lü yıllara kadar ilmin olduğunu ama bilimin olmadığını ifade eder. 1900'lü yılların başlarında tam da bilim oluşturma sürecine girerken 1930'lu yıllardan sonraki nesillerin geçmişleriyle tüm bağları koparılmış ve Türk tefekkürü tekrar başa dönmek zorunda kalmıştır. ${ }^{36}$

Duralı'nın felsefe yapma biçimi tecrübe ve aklı yürütme temellidir. İçsel ve deruni olan bilgelik yolunun tam anlamıyla felsefi olmadığını ifade eder. $\mathrm{Bu}$ yönüyle mükaşefe diyebileceğimiz safhanın felsefe öncesi bir safha olduğunu belirtir. Bu safha'da felsefe belli belirsiz olarak vardır. Bu anlamda bilge iç tecrübelerini kavramları kullanarak yansıtmaktan uzaktır. ${ }^{37}$

Burada Duralı'nın ortaya koyduğu çerçeve İbn Arabi, Mevlana, Yunus Emre, Hacı Bektaş Veli'nin eserlerinin felsefi olmadığı sonucunu doğurur. Fakat Türk tasavvuf geleneği bir yönüyle büyük düşünce ürünleri ortaya koymuştur. Ortaya konulan eserlerin Aristotelesçi çizgide olmaması onların önemli düşünce ürünleri olmadığını göstermez. Zaten bu çalışmamızda yorumlaya çalıştığımız mesele tam da budur. Türk düşüncesinin bütün müktesabatına baktığımızda "nazar ve mükaşefenin" birbirlerinden ayrılmadığı görülür. Bu birliktelik "nous ve logos" birlikteliği olarakta değerlendirilebilir.

\section{Sonuç}

İslam düşünce geleneğinde bilgiye (hakikate) ulaşmada "nazar ve keşf" olarak iki ayrı yöntem mevcuttur. "Nazar", "burhan"a dayalı bir felsefi düşünmedir. "Keşf" ise bilgiyi elde etmede müşahedeye dayalı olup içsel manevi aydınlanmayla gerçekleşir. Her iki yöntemin de felsefe tarihinde uzantıları vardır. Düşünce tarihinde bu iki yöntemin katı ve keskin taraftarları olmuştur. İki ekolden "nazar", temelde düşüncenin dile gelebilirliği üzerinden yani logos'a dayalı bir felsefe yapma biçimini kullanmıştır. "Keşf ve müşahede" ise düşüncenin dile gelmesinin mümkün olmadığını veya sadece mecazlarla az bir şekilde söze gelebileceğini iddia eder. "Keşf ve müşahede" yöntemi esasında nous'a dayalıdır. Bu iki yöntemden "keşf ve müşahede" Platon'a dayan-

36 Duralı, Omurgasızlaştırılmış Türklük, s. 92.
37 Duralı, Omurgasızlaştırılmış Türklük, s. 71.

ÇÜiFD, 2018, cilt: 18, sayı: 1, ss. 513-533 
dırılırken "nazar" yöntemi Aristoteles'e dayandırılmıştır. Bu iki yöntemi bir araya getirmeye çalışan Sühreverdi olmuştur. İşrak felsefesiyle Meşşai ve İşrakî yöntemi birleştirmiştir. Başarılı olup olmadığı ayrı bir tartışma konusudur. Fahreddin Razi'de benzer bir çaba göstermiştir. Fakat bu yöntemleri zirve noktada birleştiren bir Osmanlı düşünürü Taşköprülüzade Ahmed Efendi olmuştur. Taşköprülüzade, meseleler açısından zemininde Kelam ilminin olduğu, ortasında yöntem ve konular yönüyle felsefenin olduğu, zirvesinde ise içerik ve ifade boyutuyla tasavvufun olduğu üst düzey bir dil kurmayı başarabilmiştir.

Meselemiz bu iki yöntem bağlamında bir Türk felsefesinin olabilme imkânıdır. Türk tefekkürü, bu iki yöntemden hangisine dayanabilir? Veya bu iki yöntem kullanılarak başka bir yöntem ortaya konabilir mi? Eğer böyle bir imkân varsa yukarıda bahsettiğimiz hangi yöntemi veya yöntemleri kullanabiliriz? Sadece müşahedeye dayalı keşfi, manevi içsel bir anlayışa sahip olan Yalçın Koç' a göre ilmin dile gelmesi mümkün değildir. Diğer yandan yalnızca nazar, yani kavramsal tefekküre dayalı bilgi edinme şeklini kullanan Teoman Duralı'nın felsefe yapma biçimi yeterli görünmemektedir.

Modern dünyada Batı felsefesi merkezli bakış hâkim görünmektedir. Her medeniyetin kendine mahsus bir inanç dünyası ve geleneği vardır. Bu inanç ve gelenek çerçevesinde kendi dil ve düşünce imkânlarını kullanarak bir felsefi anlayış ve kavramsal çerçeve oluşturabilir. Bugün Türkiye' de çoğunluk itibariyle felsefe bölümleri felsefe yapma biçimi olarak Batı felsefesi merkezli bir anlayış ve kavramsal çerçeve kullanmaktadır. Bu felsefe yapma biçiminin temel özelliği ya kendi inanç ve geleneğini yok saymakta ya da kendi tarihsel müktesebatını Batı felsefesinin felsefi sistematiği ve kavramsal yapısı içinde yorumlamaktadır. İki anlayışta bakış açısı olarak kendi içinde problemler taşır. Sistematik ve kavramsal olarak kendisi olamayan bir felsefi anlayışın taklidi olarak bir felsefe yapması hakiki düşünce ürünlerinden ziyade taklit edilen felsefi sistemlerin fikir bayiliği olarak karşımıza çıkmaktadır.

Bizim burada üzerinde durduğumuz bakış açısı yerelden evrensele ulaşan felsefe yapma biçimidir. Bu bakış açısında içinde bulunduğu kendi medeniyetinin inanç, dil ve kültür imkânları zemininden yola çıkıp insanlığın ortaya koyduğu felsefi birikimleri ve ürünleri anlama ve yorumlamadır. Bir Türk tefekkürü ancak kendi medeniyetinin ürünlerini, kavramlarını, üst dilini ve düşünce yapısını kavramış ve bu birikim üzerine düşünen ve kendi dilinin imkânlarını kullanıp yaşanan dünya ile bağlantılar kurabilen bir felsefe yapma biçimi ile gerçekleşebilir. 
Öte yandan bir felsefe kurmanın temel taşlarından biriside düşünce ürünlerinin zemininde yatan tıp, fizik, matematik, astronomi gibi gerçeklik kürelerinin bilinmesidir. Felsefenin yapıldığı fiziksel zemin bilinmeden metafizik üzerinde felsefi okumalar yapmak yetersiz ve eksiktir. İhsan Fazlıoğlu'nun belirttiği gibi gerçeklik küresi yani fizik olmadan birinci elden felsefe yani metafizik olmaz. Kâinatı ve insanı bilmeden felsefi çalışmalar yapmak ancak bir edebiyat ürünü ortaya çıkarır. Felsefenin dayandığı ilmî zemini bilmeden ve kavramadan düşünce ürünleri ortaya koyamayız. Kindi, Farabi, İbn Sina, İbn Rüşt ve benzeri filozofların kendi zamanlarındaki tıp, astronomi, fizik, matematik gibi ilimleri bilmeden onların felsefelerini anlayıp yeni bir felsefi düşünce ortaya koymamı imkân dâhilinde değildir. Bir felsefi düşünce ortaya konulsa dahi bu düşüncenin yaşamın kendi gerçekliği içinde yerinin olmayacağı apaçık ortadadır.

Bir Türk tefekkürü ancak insanın yerel ve evrensel yönünü dikkate alarak gerçekleştirilebilir. Burada dil, inanç ve gelenek yani tarih ve coğrafya yerel yönümüz kendimizi ifade şeklimizdir. Evrensel yönümüz ise bu yerel zeminden Tanrıya, insana ve âleme dair tefekkürümüzü ortaya koymamızdır. $\mathrm{Bu}$ çalışmada noksan yorumlarımızla konuyu gündeme getirdik, meselenin hayati bir öneme sahip olduğunun farkındayız. Bu ve benzeri çalışmaların devam etmesi gerektiğine inanıyoruz. Eksiklik ve hatalarımızın sonraki çalışmalarda ikmal edilerek gelişmesini temenni ediyoruz.

\section{Kaynakça}

Dönmez, Süleyman, Emanet Ahlakı Türk Ahlak Felsefesine Giriş, Adana: Karahan Kitapevi, 2015.

Dönmez, Süleyman, Keşfedilmeyi Bekleyen Medeniyet Felsefenin Batı Dışı Referanslarına Eleştirel Bir Katkı, Adana: Karahan Kitapevi, 2015.

Duralı, Ş. T., Çağdaş Küresel Medeniyet, İstanbul: Dergah Yayınları, 2016.

Duralı, Ş. T., Omurgasızlaştırılmış Türklük, İstanbul: Dergah Yayınları, 2017.

Duralı, Ş. T., Felsefe-bilimin doğuşu, İstanbul: Dergah Yayınları, 2016.

Duralı, Ş. T. Felsefe-bilim nedir, İstanbul: Dergâh Yayınları, 2014.

Duralı, Ş. Teoman, "Felsefe ve Bilim İlişkisi",

https://www.teomandurali.com/page/10/Filosof Bilimadamı ve Felsefe-

Bilime İlişkin Mülakat, Erişim: 26.03.2018.

Fazlığlu, İhsan, Kendini Aramak, İstanbul: Papersense Yayınları, 2014.

Fazlıoğlu, İhsan, Sözün Eşiğinde, İstanbul: Papersense Yayınları, 2016. 
Fazlığlu, İhsan, Kendini Bulmak, İstanbul: Papersense Yayınları, 2016.

Fazlığlu, İhsan, Kayıp Halka, İstanbul: Papersense Yayınları, 2016.

Fazlıoğlu, İhsan, Derin Yapı, İstanbul: Papersense Yayınları, 2016.

Koç, Yalçın, Anadolu Mayası, Ankara: Cedit neşriyat, 2014.

Peters, Francis E., Antik Yunan Felsefesi Terimleri Sözlüğü, İstanbul: Paradigma Yayınları, Çev: Hakkı Hünler,2004.

Sarı, M.A, "Aristoteles'te İlk İlkelerin Bilgisi ve Nous Üzerine”, Kaygı dergisi, 2011/16.

Sühreverdi, İşrak felsefesi (Hikmet'ül-Işrak), İstanbul: İz Yayıncılık, 2012. 


\title{
A New Commentary Essay About Founding the History of Turkish Contemplation
}

Citation / ㅇ-- Tülüce, H.Â. (2018). A New Commentary Essay About Founding the History of Turkish Contemplation, Çukurova University Journal of Faculty of Divinity, 18 (1), 513-533.

\begin{abstract}
Every civilization has its own way of philosophizing. Though issues of thinking are the same but articulation and conveyance of ideas are different. With regard to the point, the universal side of thinking is almost the same in every civilization. But this similarity doesn't include the whole index. On the other point, the local view of thinking leads us to articulate our thoughts systematically in certain conceptual formation. Just on the point, an original philosophical meditation is in between universal and local forms. The universal part is related to the subjects of philosophy whereas that of local is interested in conveyance. In this sense, meaning marks universal side while conveyance of meaning ticks local form. Furthermore, "nazar" and "mukasahafa" are studied in the light of universal and local aspects. We will assess the possibility around the thoughts of Prof. Dr. Süleyman Dönmez, Prof. Dr. Teoman Duralı, Prof. Dr. Yalçın Koç and Prof. Dr. Ihsan Fazlıoğlu. Our subtitles will be "nazar" and "mukasahafa." In our work, the term "nous" which means, tin, soul, meaning, a person's true self; heart is used for stating the situation before concept and thought. And the term "logos" which means outer, mind, the systematical of thought is considered as the expression of thought. Although both terms are approached differently in Dönmez and Koç's works, they were used for the same meaning. In spite of the fact that we basically take the terms "bahth" and "mukasahafa" from the philosophy of Suhrawardi's ishrâq, the terms are frequently used in the tradition of Islamic thought, philosophy, kalam and sufism. While "nazar" depending on our article, represents the national reasoning, "mukasahafa" puts "instinct" into the centre of the process of reaching knowledge. Additionally we evaluated the combination of Fazlıoglu's the "sphere of truth" from the point of the reading of historic acquis. We compared Duralı's logos philosophy which is based on rational reasoning, and Koç's nous conception which is based on heart. We strived to express what the "heuristic construction" method of Dönmez is and what it stands for as a new method. And we also mentioned in which meaning the terms "nous" and "logos" used in the history of western philosophy and whether their exact meaning manipulated.
\end{abstract}

Keywords- Nazar, mukasahafa, nous, logos, Turkish philosophy, west philosophy 